\title{
THE MEDIATING EFFECT OF PROACTIVE MARKET ORIENTATION CAPABILITY IN ENTREPRENEURIAL ORIENTATION AND SERVICE INNOVATION
}

\author{
KAREN RAPHAELE CANTALEANO \\ GRAZIELA PERRETTO RODRIGUES \\ TOMAS SPARANO MARTINS \\ Universidade Federal do Paraná, Curitiba, Paraná, Brazil.
}

To cite this paper: Cantaleano, K. R.; Rodrigues, G. P.; Martins, T. S. (2018). The mediating effect of proactive market orientation capability in entrepreneurial orientation and service innovation. Revista de Administração Mackenzie, 19(1). doi 10.1590/1678-6971/eRAMR180038

Submission: Mar. 30, 2017. Acceptance: Oct. 25, 2017.

\section{(cc) BY} This is an open-access article distributed under the terms of the Creative Commons Attribution License.

\footnotetext{
This paper may be copied, distributed, displayed, transmitted or adapted if provided, in a clear and explicit way, the name of the journal, the edition, the year and the pages on which the paper was originally published, but not suggesting that RAM endorses paper reuse. This licensing term should be made explicit in cases of reuse or distribution to third parties. It is not allowed the use for commercial purposes.

Este artigo pode ser copiado, distribuído, exibido, transmitido ou adaptado desde que citados, de forma clara e explícita, o nome da revista, a edição, o ano e as páginas nas quais o artigo foi publicado originalmente, mas sem sugerir que a RAM endosse a reutilização do artigo. Esse termo de licenciamento deve ser explicitado para os casos de reutilização ou distribuição para terceiros. Não é permitido o uso para fins comerciais.
} 


\section{ABSTRACT}

Purpose: The purpose of this article is to verify the mediating effect of a proactive market orientation capability in the relationship between entrepreneurial orientation (EO) and service innovation in micro and small companies in the food-away from home sector. We analyzed the mediating effect of a marketing capability (proactive market capability) because, according to Morgan et al. (2009), a capability is an ability developed from a strategic orientation, and capabilities and orientations together contribute to organizational performance.

Originality/Value: The article verifies the mediating effect of a specific marketing capability, the proactive market orientation (PMO) in the proposed relationship. Most studies on market orientation (OM) treat the construct as a business strategic orientation, but few studies investigate market orientation based on the perspective of dynamic capabilities (Hou, 2008).

Design/methodology/approach: A quantitative survey was carried out using a non-probabilistic sampling technique for convenience with 168 establishments. The research was carried out in micro and small companies of the food-way from home sector of Curitiba PR, and the respondents were the managers and owners of the establishments.

Findings: The results indicate the existence of the mediating effect of $\mathrm{PMO}$ in the relationship between EO and service innovation.

\section{KEYWORDS}

Entrepreneurial orientation. Proactive market orientation capability. Marketing capability. Service innovation. Micro and small business. 


\section{INTRODUCTION}

This study's objective is to verify the mediating effect of a specific marketing capability, proactive market orientation (PMO), in the relationship between entrepreneurial orientation (EO) and service innovation. The research was carried out in micro and small companies of the food-way from home sector in the city of Curitiba, Paraná, Brazil.

The concept of entrepreneurial orientation was first proposed by Miller (1983) and is defined as the strategic posture adopted by the company that renews the market offers, takes risks to try new products, services and markets, and is still more proactive than its rivals in relation to new market opportunities (Lumpkin \& Dess, 1996; Miller, 1983; Wiklund \& Shepherd, 2005). Therefore, this strategic orientation is considered an important performance driver; it makes the firm to be more innovative, proactive and prone to taking calculated risks (Miller, 1983).

However, according to the meta-analysis developed by Rauch, Wiklund and Lumpkin (2009), several studies show that the relationship between EO and performance is not homogeneous and can be influenced by other internal and external factors.

As for internal organizational factors, Day (1994) conceptualizes organizational capabilities as complex "packages" of accumulated skills and knowledge in organizational processes that allow companies to use their resources and coordinate their activities. Organizational resources and processes are closely intertwined, since it is the capability of the company that allows activities in an organizational process to be carried out.

However, Day (2011) points out the existence of theoretical gaps in the literature regarding marketing capabilities. The author suggests that, with the dynamism and speed of changes in the external environment, companies need to have ways to identify and anticipate these changes.

The authors Barrales-Molina, Martínez-López, and Gázquez-Abad (2014) based their work on the dynamic capabilities framework and identify marketing dynamic capabilities as a specific kind of dynamic capability. These authors argue that proactive market orientation (PMO) meets the requirements to be considered a higher order (dynamic) capability and, therefore, a dynamic marketing capability, since it is linked to information acquisition and market knowledge.

The PMO's main characteristic is to identify and anticipate needs, not only consumers' needs, but also market needs as a whole and offer solutions through product and service innovation (Narver et al., 2004). 
Innovation in companies has been recognized as one of the main sources of competitive advantage (Schumpeter, 1934), including in the service industry, which, in recent years, has been growing and becoming very dynamic (Mcdermott \& Prajogo, 2011). However, it is important to consider that innovation in services is different from innovation in products (manufacturing), especially since services are characterized by being intangible, heterogeneous, perishable, and their production and consumption are simultaneous, with increasing interactivity with the customer (Lovelock, 1983; Randhawa \& Scerri, 2015; Sampson \& Spring, 2012).

Agarwal and Selen (2011) conceptualize service innovation as a "high service offer" that is made from a new connection with the customer; and / or a new way of service delivery; and / or a new organizational system or a new marketing proposition; and / or productivity and performance improvement through human resource management.

The literature of strategy presents the construct proactive market orientation (PMO) as a strategic company's orientation (Narver \& Slater, 1995; Narver, Slater, \& McLachlan, 2004); other studies such as BarralesMolinas et al. (2014) deal with PMO as a marketing capability. It is known that entrepreneurial-oriented companies tend to be proactive, innovative and willing to take risks (Miller, 1983) in their operations. Therefore, this characteristic of the organizational entrepreneur, added or mediated by a capability to proactively anticipate the market (PMO), can be important to evaluate the performance, whether incremental or radical, on service innovation and thus contribute to the field of organizational entrepreneurship, marketing and service innovation.

Based on presented arguments, this article argues that the marketing capabilities, specifically the PMO (the company's ability to know the market in advance and offer solutions), play a mediating role in the EO conversion into service innovation.

We try to answer the following research question: What is the mediating effect of PMO's marketing capability on the relationship between EO and service innovation?

Thus, this research aims to provide a better understanding of the impact of EO in service innovation, showing that the PMO is a relevant factor to explain this process. Furthermore, this research tries to expand the knowledge about dynamic marketing capability (PMO), which is a recent concept that should be more explored in marketing literature and organizational strategy in general. For managers, clarification on how to develop a larger PMO, influenced by EO, helps in the allocation of resources for the development of more effective strategies. These contributions become even more relevant 
when applied in the gastronomic sector, which is highly dynamic, and therefore necessary for small and medium entrepreneurs need to be more assertive.

\section{LITERATURE REVIEW AND HYPOTHESIS}

In this section we will present the concepts of entrepreneurial orientation, proactive market orientation (as a marketing capability) and service innovation in services, as well as the relationships between these concepts.

\subsection{Entrepreneurship Orientation}

Entrepreneurial orientation origins in the strategic management literature (Mintzberg, 1973), whose strategy elaborating process is considered a great organizational phenomenon which incorporates planning, analysis, decision making, and many aspects of organizational culture, values and mission (Hart, 1992). The development of a strategy is important in terms of action and commitment of resources, thus, Rauch et. al (2009) argue that EO represents the policies and practices that provide the basis for entrepreneurial actions and decisions. They also see EO as a process of elaborating the entrepreneurial strategy that the company's decision makers use to achieve organizational goals, sustain their vision and create competitive advantage.

Before defining entrepreneurial orientation, Lumpkin and Dess (1996) make a conceptual distinction between entrepreneurship and EO. This distinction is compared to that made in the strategic management literature between content and process (Bourgeois, 1980). For these authors, entrepreneurship refers to the content of the strategy and its main question is: "In which business should one enter?" The answer to this question will guide the relationship between product and market and will also direct the implementation of the resources available in the company. Considered by Lumpkin and Dess (1996) as "new entrants", they will explain what entrepreneurship consists of. EO refers to the entrepreneurial process, including the methods, practices and style of decision making that managers use to act in an entrepreneurial way (Lumpkin \& Dess, 1996), including experimenting with new technologies, being willing to take advantage of new market opportunities, and being predisposed to take risks. EO describes how "new entrants" are undertaken. In summary, the authors define EO as a process of elaboration of the strategy that provides the basis for decisionmaking and entrepreneurial actions. 
However, Miller (1983) was one of the first authors to present an organizational view of entrepreneurship. He stated that, instead of focusing on the specific individual traits, the focus should be on the entrepreneurial activity within the organizations. Therefore, for Miller (1983) an entrepreneurial enterprise is one that engages in product / market innovation, that is willing to take risks, and is proactive in its actions, outperforming its competitors.

Covin and Slevin (1991) suggest that organizational entrepreneurship has to do with organizational behavior, that is, it is an entrepreneurial posture. For the authors, organizations with an entrepreneurial attitude are those with a particular and recurrent behavioral pattern, which are present in all organizational levels and reflect the company's strategic philosophy in effective management practices. Companies with such posture have the characteristics of being innovative, proactive and willingness to take risks (Miller, 1983; Covin \& Slevin, 1991).

Table 1 presents a brief definition of EO dimensions according to Miller (1983).

\section{(Table 1)}

ENTREPRENEURIAL ORIENTATION DIMENSIONS AND DEFINITIONS

\begin{tabular}{ll}
\hline \multicolumn{1}{c}{ EO Dimensions } & \multicolumn{1}{c}{ Definition } \\
\hline Innovativeness & $\begin{array}{l}\text { Willingness to innovate, to introduce novelties through creativity and } \\
\text { experiments focused on the development of new products and services, } \\
\text { as well as new processes. }\end{array}$ \\
\hline Proactivity & $\begin{array}{l}\text { Seeking opportunities, advancing by introducing new products and } \\
\text { services and to act anticipating future demands to create change and } \\
\text { shape the environment }\end{array}$ \\
\hline Risk-taking & $\begin{array}{l}\text { Tendency to act boldly. Venturing into new and unfamiliar markets, relying } \\
\text { on a large portion of resources to risk with uncertain results, get loans } \\
\text { heavily. }\end{array}$ \\
\hline
\end{tabular}

Source: Adapted from Miller (1983).

Innovativeness is considered an essential dimension of EO because it reflects the search for new opportunities, ideas and experiences, which can be manifested in the form of innovation in products, services and processes. For Covin and Slevin (1991) entrepreneurship at the organizational level cannot exist without innovation. These authors understand that the innovation practiced in the company reflects the competitive actions that support new ideas, discoveries, experimentations, and the creation of 
processes and products. According to Miller and Friesen (1982) there are two strategic models with innovation in the entrepreneurial process: the entrepreneurial model of innovation and the conservative model of innovation. The first model concerns organizations that innovate regularly and strongly, and still take considerable risks. The second model indicates that innovation happens only when there are strong market pressures. The authors emphasize that innovation also involves a greater risk, since investments in innovation may not have the expected return.

According to Miller (1983), Covin and Slevin (1989), a proactive company is an organization that is ahead in new product and technological development and in introducing new products or services, rather than simply following the market. In other words, for Lumpkin and Dess (1996), a proactive company is a leader rather than a follower because it has the will and the vision to take advantage of the new opportunities, even if it is not the first one to do so. The authors define proactivity as a continuum, whereas its opposite is passivity, which is considered as the inability to seize opportunities or lead the market. Differently, the reactivity suggests a response to the competitor (competitive aggressiveness). Thus, proactivity can be understood as the search for new opportunities related or not with the company's present activities, making the company a pioneer among its competitors (Lumpkin \& Dess, 1996; Venkatraman, 1989).

Wiklund and Shepherd (2005) argue that the risk-taking dimension represents the willingness and ability with which the company has to devote more resources to projects with unpredictable results. Miller and Friesen (1982) define risk-taking propensity as manager' willingness to make large and risky resource commitments. EO is considered an important dimension, since it refers to the degree of risk inherent in the various strategic decisions, such resource allocation, choice of products, and markets, thus reflecting a criterion for decisions and a pattern for making organizational decisions (Venkatraman, 1989).

In relation to organizational performance, Rauch et al. (2009) emphasize that companies can benefit from an entrepreneurial orientation. The authors state that in a rapidly changing environment where the product and business life cycle is shorter, the profitability of these operations is uncertain and companies need to constantly seek new opportunities. Thus, an entrepreneurial orientation is conceived as the strategic posture that renews the market offers, takes risks to try out new products, services and markets, and is more proactive than rivals in relation to new market opportunities (Miller, 1983; Lumpkin \& Dess, 1996; Wiklund \& Shepherd, 2005). Therefore, this 
strategic orientation to be innovative, proactive and risk-taking is considered an important performance driver (Miller, 1983).

Covin and Slevin (1989), complementarily, affirm that companies with an entrepreneurial attitude are characterized by frequent and extensive innovation. Innovation is considered a key factor for entrepreneurial-oriented firms, since innovation reflects the means through which firms seek new opportunities (Covin \& Slevin, 1989; Lumpkin \& Dess, 1996; Zahra \& Covin, 1995).

\subsection{Proactive Market Orientation Capability (PMO)}

In order to understand how firms achieve competitive advantage, Day's theoretical essay (1994) seeks to identify organizational capabilities in market-oriented firms. The author specifies the difference between resources and capabilities assuming that a monetary value cannot be given to capabilities, and that they are a fundamental part of the organization's routines and practices, and can't be negotiated or imitated. Furthermore, the author conceptualizes organizational capabilities as complex "packages" of accumulated skills and knowledge in organizational processes that allow companies to use their resources and to coordinate their activities. Organizational resources and processes are closely intertwined, since it is the capability of the company that allows activities in an organizational process to be carried out.

Influenced by Day's study (1994), authors Vorhies and Harker (2000) investigated the most important marketing capabilities for market-oriented firms. Their findings include market research capability, pricing capability, new product development capability, distribution channel management capability, promotion capability and marketing management capability. Of which the latter has two forms: management of marketing projects and management of new clients. In this sense, Vorhies and Harker (2000) emphasize that, although they have the same objective of meeting the needs of customers, companies will always present different solutions to them. That is, each company can develop similar but never identical marketing capabilities, ensuring that marketing capabilities are inimitable.

Day (2011) points out the existence of theoretical gaps in the literature regarding marketing capabilities. The author suggests that with the dynamism and speed of changes in the external environment, companies need to have ways to identify and anticipate these changes. In his theoretical model, Day (2011) highlights the adaptive capabilities being: vigilant market learning that seeks to anticipate market needs; the adaptive market experimentation, 
that is, learning through experimentation; and customer relationships through social networks and other media. The author considers static capacities those that are stable, that is, those in which the processes follow a simple and systematic routine, whose focus is the inside of the company. Dynamic capabilities can be reconfigured to reach new opportunities, and adaptive capabilities anticipate these environmental changes through learning and experimentation (Day, 2011), the focus in this case is the outside in.

Morgan (2012) has shown in his theoretical model a classification of marketing capabilities with the objective of treating these capacities in a strategic way, indicating their direct relationship with organizational performance. Resources are assets controlled by the company, which serve as inputs to organizational capabilities and provide the "raw materials" for business and marketing strategies of companies. Thus, for the same author, marketing resources can be defined as assets available to managers who, when transformed by the company's marketing capabilities, can create valuable results. Morgan (2012) also emphasizes that organizational capabilities are developed when individuals and / or groups repeatedly apply their knowledge and skills to combine and transform resources in ways that contribute to the achievement of the company's goals. The author states that they occur at different levels: from the individual to the corporate. At the individual level, capabilities are commonly referred to as "competencies" in management literature. At the business unit level, four main types: specialized, cross-functional, architectural, and dynamic.

Barrales-Molina et al. (2014) suggest the role of dynamic marketing capabilities through two key elements: absorptive capability and knowledge management. Based on their extensive research on dynamic marketing capability, the authors state that marketing resources and capabilities have great potential to collect new market knowledge and to disseminate them throughout the organization, helping to build dynamic capabilities. Market knowledge is the key issue in these works.

Thus, these authors assert that a dynamic marketing capability must fulfill two conditions: first, it must contribute to the renewal of the company's resources and capabilities base; and, second, the capability needs to have specific marketing characteristics, such as acquiring market knowledge and coordinating cross-functional marketing processes, thereby absorbing and transferring that knowledge across the organization. Therefore, BarralesMolina et al. (2014) argue that proactive market orientation (Narver et al., 2004) is, by definition, a dynamic marketing capability. 
According to Narver et al. (2004) proactive market orientation (PMO) implies the effort to understand and satisfy customers' latent needs, unlike the responsive $\mathrm{MO}$ that refers to the company's attempt to understand and satisfy the expressed needs; that is, the known and manifested customer needs. Meeting customers' latent needs requires a focus on exploratory market knowledge and generative learning style (Baker \& Sinkula, 2007), unlike the adaptive learning trend generally associated with responsive MO (Narver et al., 2004). PMO helps a firm to regenerate capabilities and redefine business in dynamic markets. (Slater \& Narver, 1995). For BarralesMolina et al. (2014), only PMO can provide a generative learning style to reconfigure the firms' resource base.

In this study, proactive market orientation is not approached as a strategic orientation (Narver et al., 2004), it is understood as an organizational marketing capability.

\subsection{Service Innovation}

Innovation has been extensively studied in organizational strategy literature. For example, Schumpeter (1934) classifies economic systems as static and in development, the difference being in the presence or absence of innovation. In the static system the economic growth happens with the increase of the quantities produced. In the developing system economic growth only occurs when there is a change in the structure of the system; that is, it only occurs when there is innovation. Later, the same author subdivides innovation as "radical" innovation, when there is stronger ruptures, and "incremental" innovation, the process of change maintenance. Moreover, the author points out that innovative companies are pioneer companies because they gain competitive advantage over their competitors (Schumpeter, 2005).

Innovation has been recognized as one of the main sources of competitive advantage in companies, including in service sectors, which have been driving great growth and dynamism over the past few years in terms of economic activity (Mcdermott \& Prajogo, 2011).

It is important to emphasize, however, that innovation in services is different from innovation in products (manufacturing); fundamentally because services are characterized by being intangible, heterogeneous, perishable, and their production and consumption are simultaneous, with increasing interactivity with the customer (Lovelock, 1983; Randhawa \& Scerri, 2015; Sampson \& Spring, 2012). 
The intangibility of services makes service innovation relatively difficult to protect itself from imitations through patents; besides, their performance is assessed on the basis of user perception (Trott, 2012; Miles, 2005). The heterogeneity of services means that innovative service activities must be adapted to different contexts, which requires a more dynamic approach when compared to product innovation (Randhawa \& Scerri, 2015). Services are perishable and this means that they cannot be stored and resold as tangible products (Lovelock, 1983). Furthermore, services are produced, delivered, and consumed simultaneously, making it more difficult to distinguish between product-type service innovation, product service innovation, service delivery and process innovation, which refers to how the service / product is produced, delivered and consumed (Bessant \& Tidd, 2007; Trott, 2012). Finally, the process of innovation in services involves a high degree of interactivity between the service provider and the client. The intangible nature of services, in relation to products, makes this "exchange" between clients and suppliers more open and collaborative, even more difficult to manage (Randhawa \& Scerri, 2015).

According to Agarwal and Selen (2011) innovation in services is a "superior" service offer. This means that it is done from a new way of interacting with the client; and / or a new way to deliver services; and / or a new organizational system or marketing proposition; and / or improving productivity and performance through human resource management.

Several authors have indicated different typologies of innovation and, specifically, service innovation (March, 1991; Avlonitis, Paspatathopoulou, \& Gounaris, 2001; Brentani, 2001; Jansen, Bosch, \& Volberda, 2006). One of the main criteria used to establish typologies in this area is the degree of radical innovation. March (1991) mentions that innovation exploration is associated with radical changes in existing offerings. That is, it is related to the search for new opportunities and has a spirit of invention and experimentation. Innovation exploitation is associated with changes in existing product lines and services. This means that knowledge is to improve existing product / service offerings and satisfy current customers (Jansen et al., 2006).

Regarding innovation in gastronomic enterprises, they are generally classified as incremental or radical service innovations (March, 1991; Jansen et al., 2006). These firms are usually characterized by non-technological innovation, such as innovation in store layout, meal offerings and customer service. Even so, service retailing often outsources technology products to improve customer service. Gastronomic ventures can, for example, use 
self-service technologies in their stores, create virtual stores and use mobile apps to increase customer interaction (Pantano, 2014).

EO increases performance, as service innovation (Miller, 1983; Lumpkin \& Dess, 1996; Wiklund \& Shepherd, 2005; Rauch et al., 2009), including services in gastronomic enterprises. It is important to find out what resources can influence this relationship, increasing innovativeness, proactivity and propensity to take risks for companies to develop a true competitive advantage. There is evidence that a strategic orientation develops capabilities (Morgan et al., 2009), and, considering that the industry is dynamic and competitive, one of these capabilities is the PMO (Narver, Slater, \& Maclachlan, 2004; Barrales-Molina et al., 2004).

The main argument of this study is that companies that are entrepreneurially oriented and possess the marketing capabilities (PMO), that is, that are able to anticipate their actions towards customers, competitors and market to satisfy their latent needs, will achieve a higher degree of service innovation.

Thus, based on the theoretical concepts presented, the following research hypotheses are proposed:

H1: Entrepreneurial orientation has a direct and positive effect on service innovation.

H2: The PMO marketing capability mediates the relationship between entrepreneurial orientation and service innovation.

\section{METHODOLOGY}

The sample of this research is composed of micro and small companies, according to Brazilian Supporting Service of Micro and Small Businesses' [SEBRAE] size classification (Brazilian Supporting Service of Micro and Small Businesses) for retailing and service, that belong to the food-way from home sector in Curitiba (Paraná, Brazil). This criterion says that micro enterprises are those with up to 9 employees and small companies have between 10 and 49 employees (SEBRAE, 2017).

We used a quantitative approach through a survey using a convenient sample. The data collection instrument was a self-administered questionnaire, whose application was carried out personally for each participant, and also by e-mail with a Qualtrics link. Respondents were the business owners or managers.

We used scales that were previously used in the literature to make our questionnaire. In order to measure the entrepreneurial orientation, the 
Miller (1983) scale was used, which was refined by Covin and Slevin (1989) and later by Baker and Sinkula (2009), since these authors are precursors of EO. The scale includes three dimensions: innovation, proactivity and propensity to take risk; and has eight items. The PMO dynamic capability was measured using the eight-item MOPRO scale developed by Narver et al. (2004). The service innovation construct was measured using the Jansen et al. (2006) scale with 12 indicators, considering the exploration and exploitation classification of innovation. The Entrepreneurial Orientation (EO) items are presented in Table 2 .

\section{(Table 2)}

\section{ENTREPRENEURIAL ORIENTATION SCALE}

\begin{tabular}{cl}
\hline 1 & $\begin{array}{l}\text { (INNOV1) Our company gives a strong emphasis on research and development of new } \\
\text { technologies and innovation for food products / services. }\end{array}$ \\
\hline 2 & $\begin{array}{l}\text { (INNOV2). In recent years our company has developed new product lines / services. } \\
\text { (E.8. meal, menu, service system, etc.). }\end{array}$ \\
\hline 3 & $\begin{array}{l}\text { (INNOV3) Regarding competitors, our company always initiates innovative actions that } \\
\text { are followed by other companies. }\end{array}$ \\
\hline 4 & $\begin{array}{l}\text { (PROACT1) Our company is frequently the first to introduce new products / services, new } \\
\text { management techniques, new technologies, etc. }\end{array}$ \\
\hline 5 & $\begin{array}{l}\text { (PROACT2) Our company always adopts a competitive position with respect to other } \\
\text { competing companies. }\end{array}$ \\
\hline 7 & $\begin{array}{l}\text { (RISK1) Our company is inclined to take high risks, with chances of high return. } \\
\text { actions are necessary to achieve our objectives. }\end{array}$ \\
\hline 8 & $\begin{array}{l}\text { (RISK3) When decision-making involves uncertainties, our company takes a bold and } \\
\text { aggressive stance in order to maximize the potential opportunities that appear. }\end{array}$ \\
\hline
\end{tabular}

Source: Elaborated by the authors.

The Marketing Capability (Proactive Market Orientation) scale is presented on Table 3.

\section{(Table 3)}

\section{PROACTIVE MARKET ORIENTATION SCALE}

9 (PMO1) We bring market trends before our customers ask.

10 (PMO2) We continually try to uncover additional, unconscious needs of our customers. 


\section{(Table 3 (conclusion)) \\ PROACTIVE MARKET ORIENTATION SCALE}

\begin{tabular}{cl}
\hline 11 & $\begin{array}{l}\text { (PMO3) We incorporate solutions for our clients' non-explicit needs into our products } \\
\text { and services. }\end{array}$ \\
12 & $\begin{array}{l}\text { (PM04) We discuss internally and generate ideas / solutions together about how our } \\
\text { customers use our products/services. }\end{array}$ \\
\hline 13 & (PM05) We innovate even if it makes our products obsolete. \\
$14 \quad \begin{array}{l}\text { (PM06) We seek opportunities in areas where our clients find it difficult to express } \\
\text { their needs. }\end{array}$ \\
\hline $15 \quad \begin{array}{l}\text { (PM07) We act together with our most frequent customers to recognize customer needs } \\
\text { in general. }\end{array}$ \\
\hline 16 & $\begin{array}{l}\text { (PM08) We extrapolate market trends to gain insight into what current users will need in } \\
\text { the future. }\end{array}$ \\
\hline
\end{tabular}

Source: Elaborated by the authors.

The scale items of the Service Innovation construct are presented in Table 4.

\section{(Table 4)}

\section{SERVICE INNOVATION SCALE}

17 (EXPT1) We often refine the existing services.

18 (EXPT2) We regularly implement small adaptations for existing services.

19 (EXPT3) We introduce the improved version of our existing services in the market.

20 (EXPT4) We have improved the efficiency of our service.

21 (EXPT5) We standardize our products / services to serve a greater number of people in

21 the market in which we operate.

22 (EXPT6) Our company expands services to its current customers.

23 (EXPR1) Our company accepts demands that go beyond existing services.

24 (EXPR2) We invent new services.

25 (EXPR3) We try new services in the market.

26 (EXPR4) We sell services that are completely new to our company.

27 (EXPR5) We often promote new opportunities in new markets.

28 (EXPR6) Our company regularly uses new distribution channels. 
The three constructs were measured using a 10-point Likert scale where the respondent could mark any point between 1 (totally disagree) and 10 (totally agree). The questionnaire had 28 items (from the entrepreneurship orientation, PMO and service innovation), whose reliability and validity were already proven, and items about company and respondent profiles were added. To facilitate the tabulation and analysis of the data, as well as to make the filling process more practical, closed questions were used in relation to the respondent profile.

Data collection involved four strategies: (a) participation in the main annual industry meeting; (b) meetings with companies associations; (c) via Qualtrics and (d) directly in the company. These strategies together resulted in 186 answered questionnaires, representing a return rate of approximately $60 \%$. The next step was the data purification process, where 18 cases were considered outliers, resulting in 168 valid questionnaires.

After removing the outliers, the scales reliability test and the exploratory factor analysis were performed. For the hypothesis test, a confirmatory factor analysis (Structural Equation Modeling - SEM) was performed. The manipulation and treatment of the data in the statistical techniques were done in the software SPSS (Statistical Package for Social Sciences) and Smart PLS.

In the following table it is possible to verify the types of ventures according to Brazilian Association of Bars and Restaurants [ABRASEL]. Although the business ventures fall into more than one category, such as in some buffet restaurants that are also pizzerias, the case was classified according to its main activity.

\section{(Table 5)}

KIND OF GASTRONOMIC BUSINESS VENTURE

\begin{tabular}{clcc}
\hline Item & \multicolumn{1}{c}{ Type } & Quantity & $\%$ \\
\hline 1 & Bar & 5 & 2,9 \\
\hline 2 & Night Club & 12 & 7,1 \\
\hline 3 & Menu Restaurant & 43 & 25,6 \\
\hline 4 & Buffet Restaurant & 20 & 11,9 \\
\hline 5 & Buffet per Weight Restaurant & 21 & 12,5 \\
\hline 6 & All you can eat Restaurante & 12 & 7,1 \\
\hline 7 & Pizzaria & 8 & 4,8 \\
\hline
\end{tabular}




\section{(Table 5 (conclusion))}

KIND OF GASTRONOMIC BUSINESS VENTURE

\begin{tabular}{clcc}
\hline Item & \multicolumn{1}{c}{ Type } & Quantity & $\%$ \\
\hline 8 & Fast Food & 30 & 17,9 \\
\hline 9 & Bakery/Pastry & 17 & 10,1 \\
\hline Total & & 168 & $100 \%$ \\
\hline
\end{tabular}

Source: Elaborated by the authors.

\section{RESULTS ANALYSIS}

EO, PMO and service innovation constructs presented reliability with Cronbach's alpha value above 0.8 (Hair Jr, Hult, Ringle, \& Sarstedt, 2014). Table 6 presents the Cronbach's Alpha of each scale used in this study, showing that all reached desirable levels of reliability.

\section{(Table 6)}

RELIABILITY TEST - SCALES

\begin{tabular}{lcc}
\multicolumn{1}{c}{ Variables } & Number of Indicators & Cronbach's Alpha \\
\hline EO & 8 & 0,847 \\
\hline PMO & 8 & 0,830 \\
\hline SERV INNOV & 12 & 0,873 \\
\hline
\end{tabular}

Note: SERV INNOV - Service Innovation, EO - Entrepreneurial Orientation and PMO - Proactive Market Orientation.

Sources: Elaborated by the authors.

The exploratory factor analysis of each construct was performed in SPSS 1.8. and corroborated the theory. The EO construct carried in three factors with significant loadings (Appendix 1), that is, above 0.7 (Hair Jr et al., 2014). The construct dynamic marketing capability of PMO presented low commonality in two items, and, for that reason, another exploratory factor analysis was done excluding these two items, thus achieving satisfactory factor loadings. Finally, the service innovation loaded in two factors (exploration and exploitation - as predicted in the theory), with equally satisfactory factor loadings. However, in order to test the hypothesis in the SMART PLS 3.0 statistical software, we had to make some adjustments, removing five items of this scale. 
Table 7 shows the Composite Reliability (CR) values, which were all above 0.60 and the convergent validity of the constructs analyzed in the study, which presented an adequate AVE (Average Extracted Variance), since they are all above 0.50 (Hair Jr et al., 2014).

\section{(Table 7)}

\section{CONSTRUCTS COMPOSITE RELIABILITY AND CONVERGENT VALIDITY}

\begin{tabular}{lll}
\multicolumn{1}{c}{ Variables } & CR & AVE \\
\hline EO & 0,881 & 0,516 \\
\hline Innovativeness & 0,810 & 0,681 \\
\hline Proactivity & 0,825 & 0,701 \\
\hline Risk Taking & 0,918 & 0,788 \\
\hline PMO & 0,877 & 0,543 \\
\hline Service Innovation & 0,874 & 0,502 \\
\hline Exploration & 0,888 & 0,725 \\
\hline Exploitation & 0,922 & 0,747 \\
\hline
\end{tabular}

Note: EO - Entrepreneurial Orientation and PMO - Proactive Market Orientation.

Source: Elaborated by the authors.

After verifying the constructs convergent validity, an analysis of the discriminant validity was performed following the Fornell-Larcker (1981) criterion. This discriminant validity occurs when a construct has a higher value than the AVEs of the other constructs that are in the proposed model (Hair Jr et al., 2014), as shown in Table 8.

\section{(Table 8)}

CONSTRUCT DISCRIMINAT VALIDITY - FORNELL-LARCKER CRITERIA

\begin{tabular}{lccc} 
& SERV INNOV & EO & PMO \\
\hline SERV INNOV & 0,708 & & \\
\hline EO & 0,608 & 0,719 & \\
\hline PMO & 0,569 & 0,671 & 0,737 \\
\hline
\end{tabular}

Note: SERV INNOV - Service Innovation, EO - Entrepreneurial Orientation and PMO - Proactive Market Orientation. 
The model presented convergent and discriminant validity, so the hypotheses were tested in the PLS - Partial Least Squares method through SMART PLS 3.0 software. The entrepreneurial orientation and service innovation are considered, in this research, second-order constructs, while the construct capability of proactive market orientation a first-order construct. Figure 1 presents our theoretical model.

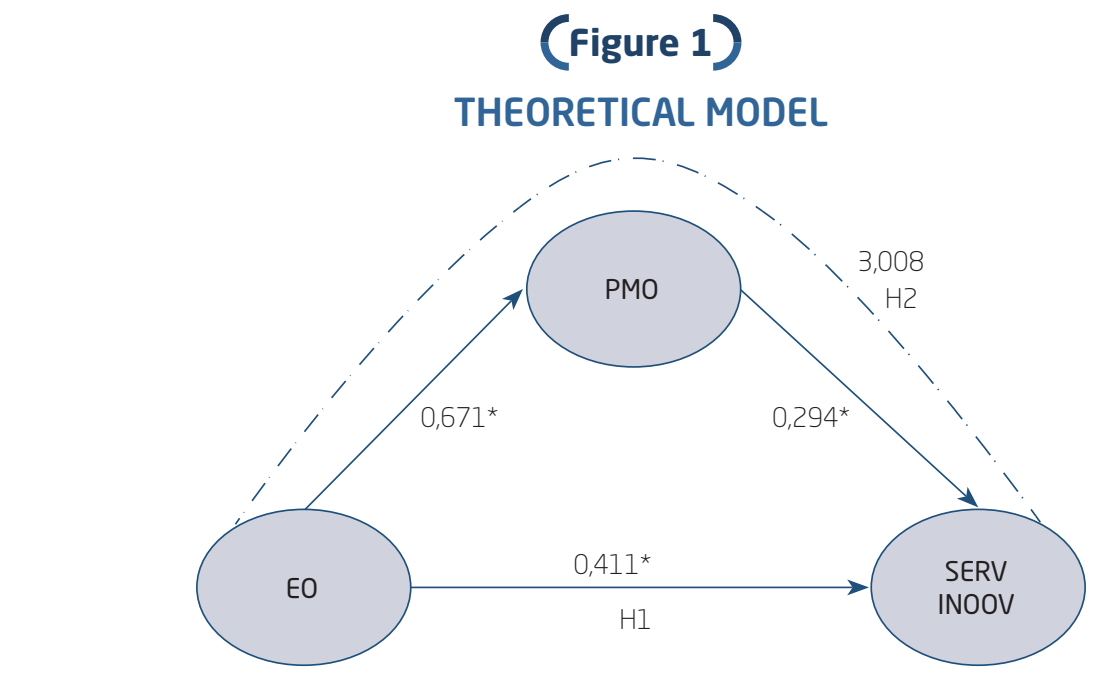

* Significant values at the level $p \geq 0,05=1,96$.

Source: Elaborated by the authors.

Hypothesis 1 verified the relationship between EO and service innovation. The test of this hypothesis resulted in a path coefficient of 0.411 , indicating an important relation between the two variables. The $t$ value was 4.186 (> 1.96), showing the significance of the relationship at a confidence level of $95 \%$, that is, $\mathrm{p}<0.05$ (Hair Jr et al., 2014). This means that EO directly and positively affects service innovation. This result indicates the importance of EO in organizations, because EO is perceived as the processes, practices and activities that result in innovation. (Slater \& Narver, 1993; Slater \& Narver, 1995). These findings corroborate the results found by Salunke, Weerawardena, and McColl-Kennedy (2013) that service entrepreneurship contributes significantly to service innovation and is considered an important source of competitive advantage. Thus, it can be understood that EO contributes to innovation, since it is a strategic orientation that reflects the search for new opportunities, ideas and experiences, and that can be manifested in the form of innovation in products, services and processes (Miller, 1983; Covin \& Slevin, 1991; Lumpkin \& Dess, 1996; Wiklund \& Shepherd, 2005). 
The hypothesis test results are also in accordance with Madhoushi, Sadati, Delavari, Mehdivand, \& Mihandost (2011) that EO is a key ingredient for business innovation. These authors have found that this orientation has a positive impact on innovation, either directly or indirectly, indicating that there is a mediating role of the knowledge management construct.

The second hypothesis of this study tested the effect of PMO mediation between EO constructs and service innovation, and it was supported $(\beta=0.294$ and $t=3.008)$. This result corroborates Morgan et al. (2009) findings that organizational skills are skills built on a strategic orientation. EO is one of them, and can then favor the development of organizational capabilities, in this case the dynamic marketing capacity of PMO. It corroborates the findings of Salunke et al. (2013), who argue that entrepreneurship-oriented firms make a major contribution to service innovation. It confirms, also, the results found by Madhoushi et al. (2011) that demonstrated that EO has a positive impact on innovation, either directly or indirectly, indicating that there is a mediating role of the knowledge management construct. Another example is the article by Alegre and Chiva (2013) that found that organizational learning partially mediates the relationship between $\mathrm{EO}$ and innovation performance, and innovation performance completely mediates the EO relationship and organizational performance.

This result indicates that entrepreneurial oriented companies, which have the ability to proactively anticipate the market, that is, that seek to meet unexpressed market, customers, competitors' needs and propose solutions for these needs, result in service innovation.

Table 9 summarizes the test results for the hypotheses.

\begin{tabular}{|c|c|c|c|}
\hline \multicolumn{4}{|c|}{ HYPOTHESIS RESULTS } \\
\hline Hypothesis & $\begin{array}{l}\text { Path coefficient } \\
\qquad(\beta)\end{array}$ & t-value & Hypothesis \\
\hline $\begin{array}{l}\mathrm{Hl} \text { : EO has a direct and positive effect on } \\
\text { service innovation. }\end{array}$ & 0,411 & 4,186 & Accepted \\
\hline $\begin{array}{l}\text { H2: The PMO marketing capability acts as a } \\
\text { mediating variable, and has an indirect and } \\
\text { positive effect on the relationship between } \\
\text { EO and service innovation. }\end{array}$ & 0,294 & 3,008 & Accepted \\
\hline
\end{tabular}

Note: EO - Entrepreneurial Orientation and PMO - Proactive Market Orientation. 
In summary, the results show that the micro and small companies in the food-away from home sector of Curitiba (Paraná, Brazil) that are oriented to the market proactively to anticipate customer desires and needs reach a greater degree of innovation in their service offer.

\section{FINAL CONSIDERATIONS}

This article presented results that provided two theoretical contributions:

a) a better understanding of the capability of PMO effect on the relationship between EO and service innovation in micro and small firms in the food-away from home industry in the city of Curitiba-PR. This research expanded the understanding of the influence of EO on performance, showing that there are other capabilities, such as PMO, that can increase performance. This finding is important for marketing literature and strategy in general, as it shows how companies can leverage their resources to be more innovative in services.

b) the PMO was addressed in this paper as a marketing capability (BarralesMolina et al., 2014) and refers to the ability of the company to anticipate and meet the needs of latent customers, competitors, suppliers and the market in general (Narver et al., 2004). This perspective provided new knowledge on the subject and contributed to the organizational capabilities literature because we empirically tested the theory proposed by Barrales-Molina et al. (2014).

In short, this research identified that a company oriented to entrepreneurship, that is, a company that adopts an innovative, proactive attitude towards competitors and is willing to take risks, generates innovation in its service offering.

When a firm assumes an entrepreneurial attitude, it generates innovation, whether it is incremental in terms of its current services (exploitation), for example, improving efficiency or making small adaptations, or radical (exploration), that implies more sudden changes; for example: inventing and trying new services for the company and for the market.

In relation to the mediation, having the ability to anticipate market needs in order to propose solutions to meet the latent customer needs proved to be relevant for companies that are oriented to entrepreneurship in the food-away from home sector of Curitiba, Paraná. Even if it is a micro 
and/or small firm, that usually does not have many organizational resources, it is able to proactively provide solutions for turbulent markets and bring important insights that consequently can generate service innovation.

In other words, the tasks of continually uncovering customers' stillunmet needs, extrapolating market trends to gain insight into what customers will need in the future, and pursuing opportunities in areas where customers have not yet expressed need can be difficult to be carried out by a lean and often technically unprepared team, but these activities are important and essential for achieving a greater degree of service innovation.

In this type of company, strategic decisions are usually made by few people, who also often perform various operational functions in the company. Even in this situation, the result of the study showed that managers and owners who are worried about serving the latent market are more inclined to obtain innovation in the services offered.

In summary, this study verified that PMO has a mediating effect on the relationship between EO and service innovation, indicating that companies that look at the market proactively have a greater chance of success in the service innovation.

In relation to the practical contribution of this research, with this knowledge, the owners and managers of the analyzed companies in this research can direct their resources to investing in proactive market knowledge and to adopting innovative actions. In this way it will be possible to increase the results of companies, mainly in innovation services.

The limitations of this study are the non-probabilistic sample and its application in a specific sector of the economy, that is, the food-away from home sector. Therefore, it is suggested that future research use this model in different contexts and with different samples.

Since in many sectors the market is becoming more competitive and dynamic, a greater understanding of the organizational resources to overcome these challenges is necessary. Future research should explore resources that help capture and understand these turbulent market characteristics, such as the PMO, along with other strategic orientations and organizational capabilities.

\section{$\int$ REFERENCES}

Associação Brasileira de Bares e Restaurantes [ABRASEL]. (2016). Retrieved from http://www.pr.abrasel.com.br/ 
Agarwal, R. \& Selen, W. (2011). Multi-dimensional nature of service innovation: Operationalization of the elevated service offerings construct in collaborative service organizations. International Journal of Operations $\mathcal{E}$ Production Management, 16(11), 1164-1192.

Alegre, J., \& Chiva, R. (2013). Linking entrepreneurial orientation and firm performance: The role of organizational learning capability and innovation performance. Journal of Small Business Management, 51 (4), 491-507.

Avlonitis, G. J., Paspathoupoulou, P. G., \& Gounaris, S. P. (2001). An empiricallybased typology of product innovativeness for new financial services: Success and failure scenarios. Journal of Product Innovation Management, 18(5), 324-342.

Baker, W. E., \& Sinkula, J. M. (2007). Does market orientation facilitate balanced innovation programs? An organizational learning perspective. Journal of Product Innovation Management, 24(4), 316-334.

Baker, W. E., \& Sinkula, J. M. (2009). The complementary effects of market orientation and entrepreneurial orientation on profitability in small businesses. Journal of Small Business Management, 47(4), 443-464.

Barrales-Molina, V., Martínez-López, F. J., \& Gázquez-Abad, J. C. (2014). Dynamic marketing capabilities: Toward an integrative framework. International Journal of Management Reviews, 16(4), 397-416.

Bessant, J. \& Tidd, J. (2007). Innovation and entrepreneurship. New Jersey, NJ: John Wiley \& Sons.

Bourgeois, L. J. (1980). Performance and consensus. Strategic Management Journal, 1 (3), 227-248.

Covin, J. G., \& Slevin, D. P. (1989). Strategic management of small firms in hostile and benign environments. Strategic Management Journal, 10(1), 75-87.

Covin, J. G., \& Slevin, D. P. (1991). A conceptual model of entrepreneurship as firm behavior. Entrepreneurship Theory and Practice, 16(1), 7-25.

Day, G. S. (1994). The capabilities of market-driven organizations. The Journal of Marketing, 58(4), 37-52.

Day, G. S. (2011). Closing the marketing capabilities gap. Journal of Marketing, 75(4), 183-195.

Fornell, C., \& Larcker, D. F. (1981). Structural equation models with unobservable variables and measurement error: Algebra and statistics. Journal of Marketing Research, 18(3), 382-388. 
Hair Jr, J. F., Hult, G. T. M., Ringle, C., \& Sarstedt, M. (2014). A primer on partial least squares structural equation modeling (PLS-SEM). New York, NY: Sage Publications.

Hart, S. L. (1992). An integrative framework for strategy-making processes. Academy of management Review, 17(2), 327-351.

Jansen, J. J. P., Bosh, F. A. J. van den, \& Volberda, H. W. (2006). Exploratory innovation, exploitative innovation, and performance: Effects of organizational antecedents and environmental moderators. Management Science, 52(11), 1661-1674.

Lovelock, C. H. (1983). Classifying services to gain strategic marketing insights. The Journal of Marketing, 47(3), 9-20.

Lumpkin, G. T., \& Dess, G. G. (1996). Clarifying the entrepreneurial orientation construct and linking it to performance. Academy of management Review, 21 (1), 135-172.

Madhoushi, M., Sadati, A., Delavari, H., Mehdivand, M., \& Mihandost, R. (2011). Entrepreneurial orientation and innovation performance: The mediating role of knowledge management. Asian Journal of Business Management, 3(4), 310-316.

March, J. G. (1991). Exploration and exploitation in organizational learning. Organization Science, 2(1), 71-87.

Mcdermott, C. M., \& Prajogo, D. I. (2011). Service innovation and performance in SMEs. International Journal of Operations \& Production Management, 32 (2), 216-237.

Miles, I. (2005). Innovation in Services.

Miller, D. (1983). The correlates of entrepreneurship in three types of firms. Management Science, 29(7), 770-791.

Miller, D., \& Friesen, P. H. (1982). Innovation in conservative and entrepreneurial firms: Two models of strategic momentum. Strategic management journal, 3(1), 1-25.

Mintzberg, H. (1973). Strategy-making in three modes. California management review, 16(2), 44-53.

Morgan, N. A. (2012). Marketing and business performance. Journal of the Academy of Marketing Science, 40(1), 102-119.

Morgan, N. A., Vorhies, D. W. \& Mason, C. H. (2009). Market orientation, marketing capabilities, and firm performance. Strategic Management Journal, 30(8), 909-920. 
Narver, J. C. \& Slater, S. F. (1995). The effect of a market orientation on business profitability. Journal of Marketing, 54(4), 20-35.

Narver, J. C., Slater, S. F., \& MacLachlan, D. L. (2004). Responsive and proactive market orientation and new-product success. Journal of product innovation management, 21 (5), 334-347.

Pantano, E. (2014) Innovation drivers in retail industry. International Journal of Information Management, 34(3), 344-350.

Randhawa, K., \& Scerri, M. (2015). Service innovation: A review of the literature. In R. Agarwal, W. Selen, G. Roos, \& R. Green (Eds.), The Handbook of Service Innovation (pp. 27-51). London: Springer.

Rauch, A., Wiklund, J., Lumpkin, G. T., \& Frese, M. (2009). Entrepreneurial orientation and business performance: An assessment of past research and suggestions for the future. Entrepreneurship theory and practice, 33(3), 761-787.

Salunke, S., Weerawardena, J., \& McColl-Kennedy, J. R. (2013). Competing through service innovation: The role of bricolage and entrepreneurship in project-oriented firms. Journal of Business Research, 66 (8), 1085-1097.

Sampson, S. E., \& Spring, M. (2012). Customer roles in service supply chains and opportunities for innovation. Journal of Supply Chain Management, 48(4), 30-50.

Schumpeter, J. A. (1934). The Theory of Economic Development. Boston, MA: Havard University Press.

Schumpeter, J. A. (2005). Development. Journal of Economic Literature, 43, 104-116.

Serviço Brasileiro de Apoio às Micro e Pequenas Empresas [SEBRAE]. (2017). Leis. Retrieved from http://www.sebrae-sc.com.br/leis/default.[asp?vcd texto $=4154$.

Slater, S. F., \& Narver, J. C. (1993). Product-market strategy and performance: An analysis of the Miles and Snow strategy types. European journal of marketing, 27(10), 33-51.

Slater, S. F., \& Narver, J. C. (1995). Market orientation and the learning organization. The Journal of Marketing, 59(3), 63-74.

Trott, P. (2012). Innovation management and new product development. Financial Times; Prentice Hall.

Venkatraman, N. (1989). Strategic orientation of business enterprises: The construct, dimensionality and measurement. Management Science, 35(8), 942-946. 
Vorhies, D. W., \& Harker, M. (2000). The capabilities and performance advantages of Marketing driven firms: An empirical Investigation. Australian Journal of Management, 25(2), 145-171.

Wiklund, J., \& Shepherd, D. (2005). Entrepreneurial orientation and small business performance: a configurational approach. Journal of business venturing, 20(1), 71-91.

Zahra, S. A., \& Covin, J. G. (1995). Contextual influences on the corporate entrepreneurship - performance relationship: a longitudinal analysis. Journal of Business Venturing, 10(1), 43-58.

\title{
$\int$ ABOUT THE AUTHORS
}

\author{
KAREN RAPHAELE CANTALEANO \\ Master degree in Management, \\ Universidade Federal do Paraná. \\ Avenida Lothario Meissneer, 632, Jardim Botânico - Curitiba - PR - Brazil - CEP 80210-170 \\ E-mail: karenraphaele@gmail.com \\ ORCID: 0000-0001-8860-7015 \\ GRAZIELA PERRETTO RODRIGUES \\ $\mathrm{PhD}$ Candidate in Management, \\ Universidade Federal do Paraná. \\ Avenida Lothario Meissneer, 632, Jardim Botânico - Curitiba - PR - Brazil - CEP 80210-170 \\ E-mail: grazielarodrigues@gmail.com \\ ORCID: 0000-0002-5840-9859

\section{TOMAS SPARANO MARTINS} \\ $\mathrm{PhD}$ in Business, \\ Pontifícia Universidade Católica do Paraná. \\ Adjunct Professor at the Department of Business, \\ Universidade Federal do Paraná. \\ Avenida Lothario Meissneer, 632, Jardim Botânico - Curitiba - PR - Brazil - CEP 80210-170 \\ E-mail: tomas.martins@ufpr.br \\ ORCID: 0000-0001-7355-7481
}

\section{EDITORIAL BOARD}

Editor-in-chief

Silvio Popadiuk

Associated Editor

Dimária Silva e Meirelles

Technical Support Patricia Betencourt

Vitória Batista Santos Silva
EDITORIAL PRODUCTION

$\begin{array}{ll}\begin{array}{l}\text { Publishing Coordination } \\ \text { Irina Migliari }\end{array} & \begin{array}{l}\text { Language Editor } \\ \text { Caio Rubens Salles }\end{array} \\ \text { Editorial Trainee } & \text { Layout Designer } \\ \text { Maria Luiza Vanz } & \text { Emap } \\ \text { Copyeditor } & \text { Graphic Designer } \\ \text { Irina Migliari } & \text { Libro }\end{array}$




\section{(APPendiX 1)}

\begin{tabular}{|c|c|c|}
\hline \multicolumn{3}{|c|}{$\begin{array}{l}\text { Outer Loadings Entrepreneurial Orientation (EO)* } \\
\text { EO Dimension loading. }\end{array}$} \\
\hline Indicators & Dimensions & Construct \\
\hline Innovativeness & & *0,821 \\
\hline 1. (INNOV 1) (research and development) & 0,822 & \\
\hline 3. (INNOV 3) (initiates innovative actions) & 0,828 & \\
\hline Proactivity & & *0,800 \\
\hline 4. (PROACT 1) (First to introduce new products / services) & 0,843 & \\
\hline 5. (PROACT 2) (Competitive position) & 0,833 & \\
\hline Risk Taking & & * 0,873 \\
\hline 6. (RISK 1) (high risks with high return chances) & 0,899 & \\
\hline 7. (RISK 2) (audacious actions to achieve objectives) & 0,881 & \\
\hline 8. (RISK 3) (bold and aggressive posture) & 0,883 & \\
\hline
\end{tabular}

\begin{tabular}{lc}
\hline \multicolumn{2}{c}{ Outer Loadings for Proactive Market Orientation (PMO) } \\
\hline \multicolumn{1}{c}{ Indicators } & Dimensions \\
\hline 9. (PMO1) (market trends) & 0,747 \\
\hline 10. (PMO 2) (non-conscious customer needs) & 0,774 \\
\hline 11. (PMO 3) (solutions for non-explicit needs) & 0,743 \\
\hline 14. (PMO6) (opportunities where clients have difficulties expressing their needs) & 0,697 \\
\hline 15. (PMO 7) (recognize customer needs before competitors) & 0,753 \\
\hline 16. (PMO 8) (Extrapolating the trends) & 0,702 \\
\hline
\end{tabular}

\begin{tabular}{lc}
\hline \multicolumn{2}{c}{ Outer Loadings for Service Innovation } \\
\hline \multicolumn{1}{c}{ Indicators } & Dimensions \\
\hline Exploitation & ${ }^{\star 0,888}$ \\
\hline 17. (EXPT1) (we refine customer services) & 0,831 \\
\hline 18. (EXPT2) (minor adaptations) & 0,870 \\
\hline
\end{tabular}




\section{(APPENDIX 1 (conclusion))}

\begin{tabular}{lc}
\hline \multicolumn{2}{c}{ Outer Loadings for Service Innovation } \\
\hline \multicolumn{1}{c}{ Indicators } & Dimensions \\
\hline 19. (EXPT3) (enhanced version) & 0,880 \\
\hline 20. (EXPT4) (we improve efficiency) & 0,874 \\
\hline Exploration & * 0,733 \\
\hline 24. (EXPR2) (we have invented new services) & 0,873 \\
\hline 25. (EXPR3) (we try out new services) & 0,844 \\
\hline 26. (EXPR4) (we sell services that are new to our company) & 0,837 \\
\hline
\end{tabular}

Source: Elaborated by the authors. 